\title{
BIM AND LEAN CONSTRUCTION INTERACTIONS: A STATE-OF-THE-ART REVIEW
}

\author{
MARÍA DOLORES ANDÚJAR-MONTOYA ${ }^{1 *}$, ANTONIO GALIANO-GARRIGÓS ${ }^{2}$, \\ CARLOS RIZO-MAESTRE ${ }^{2} \&$ VÍCTOR ECHARRI-IRIBARREN ${ }^{2}$ \\ ${ }^{1}$ Department of Architectural Constructions, University of Alicante, Spain \\ ${ }^{2}$ Department of Building Sciences and Urbanism, University of Alicante, Spain
}

\begin{abstract}
The construction industry needs contemporary approaches in order to improve the performance of the construction process, in terms of both time and cost. Currently, the most significant trends applied for this purpose are building information modelling paradigm (BIM) and Lean construction philosophy. Following the rise of both paradigms, many studies have been conducted to explore the benefits of its application in isolation. As a consequence, the aim of this paper is to bring to knowledge a state-of-the-art overview of literature about BIM and Lean construction synergies. Firstly, a general overview of each paradigm is presented. Secondly, the synergies between both principles and their theoretical and practical applications are also covered. Finally, conclusions and recommendations for future researches are presented.
\end{abstract}

Keywords: building information modelling, BIM, Lean construction.

\section{INTRODUCTION}

During the period 2002-2009 Spain had an uncontrolled growth in the building market, this period was called the construction bubble and made housing prizes raise. This spectacular and uncontrolled growth did not only affect the private housing market, but also public administration started new developments in many cases without any control and even without the proper finance. One of the main consequences of the crash of the construction bubble was the trend related to big budget deviations in construction projects, which in many cases reached outrageous costs. The problem of cost overruns is also a reality at the international level, in relation to this some works set a mean cost overrun of $12.22 \%$ in construction and engineering projects [1], [2]. Many factors contribute to these deviations with diverse origins such as human-induced causes associated with people involved in the process, where the lack of communication is a constant barrier that appears as a consequence of the concurrence of diverse companies and participants in the construction phase, climate of competition, and tightness of the information [3]. These issues lead to information not flowing to all stakeholders or not flowing on time, generating bottlenecks, unnecessary works and reworks [4]. Indeed, up to $30 \%$ of construction activities are rework tasks [5], being understood as rework the unnecessary effort of re-doing a process or activity that was initially badly performed, affecting the budget and project planning [6]-[8]. Specifically, from 6 to $12 \%$ of construction costs are wasted on rework of defective components detected late during the construction phase [9], [10], and this situation is often aggravated by the lack of motivation and participation of subcontracted companies and own workers [11]. Furthermore, human-induced causes are reinforced by the high dependence of the construction sector on manual tasks and procedures that could be automated through the use of advanced technology. However, technology scarcity and technology gap is a constant in the sector that contributes to the general inefficient performance of the construction industry, promoting again the tightness of information, duplicities and errors and ultimately lack of transparency

* ORCID: https://orcid.org/0000-0002-8250-1954 
during the construction process [12]. Although technology represents one of the main allies for companies to optimize resources, the utilization of these technological advances in the construction industry is still quite low [13]. In addition, the inherent causes of construction projects derived from the complexity, uncertainty and variability of the construction process itself are also noteworthy [11]. Some of these unforeseen causes can be categorized as delays in the delivery of materials and equipment, design errors, changes in orders, breakdowns and malfunctions of tools, labour absences, environmental effects, accidents and physical demands of work that affect productivity [14]. These causes usually generate mismatches between what was initially programmed and what was actually built, encouraging improvisation tendencies before decision making [11]. Finally, some authors include other political causes [2]. Lack of control during the contracting and construction phase is being a worrying issue for both researchers and participants involved in the sector, who claim that a change in regulation is needed in order to avoid uncontrolled budget bids commonly known as wild bids, since there is a direct connection between these bids and budget deviations during construction [15]. Specifically, in Spain initiatives from the public and the private sector have been developed, and a sample of it is the report published by The Spanish Confederation for Entrepreneur Organizations [16] with a proposal for improving the legal Frame and the contractual procedures for hiring building companies, and at the same time, remarked the need of transparency and the improvement of the project. Also, in 2018 the Government of Spain published a new contracting law for the public sector introducing many initiatives to promote the transparency in the process of hiring a company and setting clearer steps to control quality in the construction project and the building process. At the same time measures to digitalize the construction process were introduced, proposing the use of BIM, based on the experience that other UE countries had and that many researchers have analysed [17]. As a result of the foregoing, a rethinking of the practices and procedures used until now is necessarily needed, being unavoidable the definition of new guidelines of action for greater efficiency in construction projects.

According to this idea, this paper examines the application of the most growing trends in the sector at the moment in order to improve the efficiency of the construction process, both in terms of time and cost. Currently, the most representative paradigms which are spreading more rapidly not only in the research world but also in the professional field are the collaborative work methodology building information modelling (hereinafter BIM) and the Lean Construction philosophy. BIM is an emerging technology that provides an integrated solution for managing construction projects throughout its life cycle, from the definition of project objectives to the fulfilment of its useful life, centralizing all project information in a digital information model accessible by all stakeholders [18]. Another growing approach within the construction industry is the application of the Lean Construction philosophy, and its associated tools. Lean Construction is an adaptation of the Lean Manufacturing philosophy to construction, and it focuses on improving performance during construction works through the reduction of waste while maximizing value [19]-[22], understanding waste as any activity that consumes resources but does not create value such as errors requiring rectification or reworks, unnecessary movement of labour, material and resources from one place to another without any purpose, bottlenecks or underutilized resources due to waiting or delays. One of the most effective tools within the Lean Construction background is the Last Planner system tool which enables agile and proactive management of construction projects [23]. 


\section{CURRENT APPROACHES TO OPTIMIZE THE EFFICIENCY OF CONSTRUCTION PROJECTS}

\subsection{Last planner system}

As stated in the previous paragraph, Lean Construction is based on the management of construction projects following the principles of Lean Manufacturing. One of main focus of Lean Construction is to reduce cycle time, simplifying and minimizing the number of steps, parts and links to increase production flexibility, process transparency, and to focus on controlling the entire process globally, reducing variability and establishing continuous improvement [11]. Its most significant tool within the framework of construction project management is the Last Planner system which enables agile and proactive management of construction projects, compared to traditional methods of project management that focus on activities proving ineffective, especially those based on the critical path method where the identification of deviations often occurs too late. Although these methods are widely used in the management of construction projects, for example Gantt Diagrams, their ineffectiveness in producing predictable results has been recognized in various studies, as well as the lack of adaptation to the reality of the project construction management [23]. These methods do not provide a concise description of the actual development of the project, becoming mere initial assumptions that will later be corrected and adjusted during the construction phase, often involving delays and increases in contractual deadlines [23], [24]. In addition, the interrelationships between project variables and surrounding factors are actually complex causality and effect relationships, non-linear as traditional methods suggest [25]. Faced with this Last Planner system is characterized by the generation of a predictable workflow through a collaborative planning process distinguished by participant commitment and agility. These characteristics determine the adequacy of the system for project management, especially suitable for projects in complex environments, by reducing variability, improving performance and flow reliability, thus ensuring quality, decision making, and stakeholders' commitment.

All this from different phases of the Last planner system spread over different time horizons throughout the management of the construction project: Master schedule, Phase Scheduling or Pull schedule, Look Ahead Planning and Weekly Work Plan. As it is developed in [26], Last planner system begins with an initial meeting where milestones and deadlines from the Master Schedule are established. This phase is known as Phase Scheduling, also known as Pull Schedule by the use of the Pull system to carry out the schedule of activities in a collaborative way among all participants, starting from the milestones or completion date from the end to the beginning, i.e. in reverse to the date of termination [26], [27]. This collaborative planning becomes the starting point for the Look Ahead Planning phase, which serves as a bridge between long-term planning and short-term commitments [28], where workflows of each activity in that period are identified, usually 6 weeks in advance. Then, an analysis of the restrictions that affect the beginning and development of the works is performed, categorizing them and developing a plan for their elimination before the activity begins. After that, restrictions are categorized, and a plan is drawn up for disposal before the activity begins. From the activities free of restrictions, a weekly schedule (Weekly Work Plan) is done, presenting the highest level of detail before executing the work. Finally, performance of planned activities is evaluated through the indicator Percentage Plan Completed (hereinafter PPC) that enables a comparison between what was initially programmed and actually executed. 


\subsection{BIM paradigm}

The most widespread technological improvement in the sector is the implementation of BIM as a growing trend that provides an integrated solution for managing construction projects, throughout its life cycle from the definition of project objectives to the fulfilment of its useful life [18]. It is the new technology standard based on an improvement of the building data management that is renovating the building market. This information, gathered during the building process, becomes an added value during all the building life cycle. This is achieved because BIM is based on a digital representation of the building process that facilitates the exchange and interoperability of information in digital format. In parallel BIM is being progressively introduced in the project life cycle. This is due to the fact that national administrations must adapt its construction procedures to the publication by the European Union (EU) of the European Directive for Public Procurement, which promotes the use of electronic tools like BIM in construction projects financed by EU public funds. But although some countries like The United Kingdom, Denmark, Netherlands, Norway and Finland already require BIM for public works, there are other countries, as Spain, where the awareness and the adoption among construction stakeholders is currently spreading [29], and the implementation has not started for the administration and is still at an initial stage above all for SMEs.

There are several authors that have been focused on the acceptance and implementation of BIM in the sector [30]-[34]. The use of BIM technologies during the design and construction phases avoids design mistakes allowing visualization and therefore conflicts, interferences and clash detections [35], [36] achieving savings of up to $10 \%$ of the contract value through these clash detections [36]. Indeed, BIM has been proven to reduce document errors and omissions by up to $52 \%$, it can also reduce reworks by up to $48 \%$, and reduce cycle time of specific workflows $39 \%$, and cycle time of specific workflows by up to $39 \%$ [37], [38]. Also, it is remarkable the benefits related to the cost reduction and control through the project life cycle [39] since BIM provides predictable information with regard to quantity, cost, schedules, and materials [40]. Furthermore, BIM creates and makes available information early, this fact together with the ubiquity of mobile technology that facilitates access to site information at any time and from anywhere shortens the gap between information availability and response times. In addition, BIM facilitates information flow since participants have a clear understanding of their role and responsibility in a project aligning expectations, and increases transparency as it shows how to integrate best practices and capture knowledge sharing from one project to the next, promoting continuous improvement [41].

\section{RESEARCH METHODOLOGY}

The present research started with the problem identification that has been addressed in Section 1, thus, a study of all the relevant literature regarding delays and cost overruns in construction works managed in a traditional way was performed. Subsequently, as Fig. 1 shows, a second stage included the identification of the partial solutions to face these problems. For this, extensive research was identified on BIM and Lean issues in isolation as paradigms that counteract the causes of delays and cost overruns. These current approaches to optimize the efficiency of construction projects have been briefly presented in Section 2 . It is beyond the scope of this paper to show the detailed review of BIM and Lean as isolated paradigms, since the paper sampling is only focused on the synergies of both disciplines. A detailed review can be found in previous works of the authors and also in some relevant works [11], [32], [33], [36], [42]-[45]. 


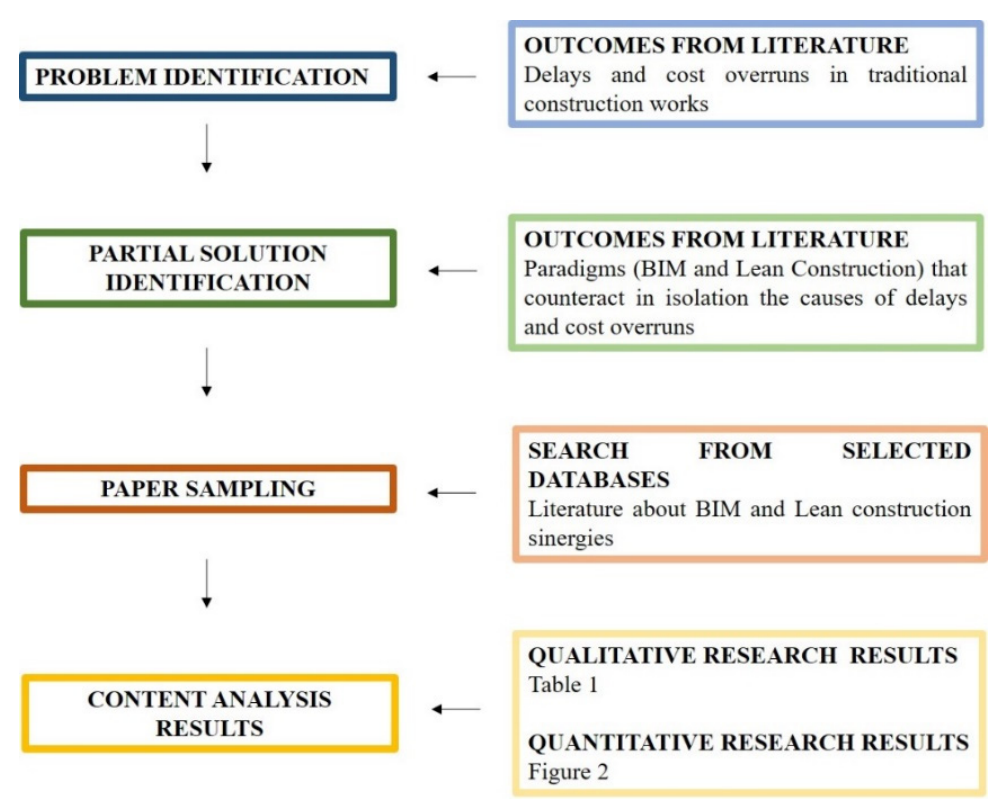

Figure 1: Flow diagram showing the research process.

In a third stage, searches for relevant articles focused on BIM and Lean construction synergies to include in the paper sampling were performed using selected databases such as Web of Science, Scopus, and Google Scholar. Accurate keywords choice is relevant to ensure a precise search. Keywords used for searching the articles included BIM, building information modelling, Lean Construction and Last planner system.

Finally, in a fourth stage the study adopted a qualitative research approach where were identified improvements brought about by the implementation of these paradigms simultaneously, in order to counteract the problem generally presented by the management of traditional construction projects that were identified in Section 1. Furthermore, a quantitative analysis of the paper sampling provided an overview about the lifecycle stage where the researches are focus on, the main discipline of the research, the research dissemination vehicle and the profile of research according to if it is a theoretical work or a case study.

\section{CONTENT ANALYSIS: RESULTS AND DISCUSSION}

According to De Carvalho et al. [46] the content analysis is a research technique that allows the collection and classification of information in order to identify trends.

The main characteristic of the content analysis is that it is a method that intrinsically combines observation and the interpretation of the data or data analysis. The present work focuses on a content analysis on the BIM and Lean synergies. Only works based on this synergy and published in scientific journals and in the most representative international conferences were included. Research and representative international conferences focused on BIM or Lean in an isolated way were not included. The papers focusing on prefabricated building system were not included either, since the issues identified in Section 1 Introduction have their origin in the traditional management of construction works carried out completely on site. 


\subsection{Qualitative research results}

Although BIM and Lean construction are two paradigms that have evolved independently, BIM acts as a facilitator and catalyst of Lean philosophy improving its application. About the mutual synergy of BIM-Lean is written in Dave et al. [47] where it is shown the relevance of these two methodologies throughout project life cycle: early design, design and detail, construction, fit-out and handover, and facilities management and operations. BIM contributes directly to Lean goals enabling Lean processes but at the same time Lean processes facilitate the adoption and use of BIM. The synergy of both paradigms has strategic advantages in the organizations that implement it, through improvements in projects related to customer focus through early identification of value, clash detection and fast evaluation of alternatives, and collaboration, among others.

Specifically in Mollasalehi et al. [48] was studied how the integration of the BIM technology capability with the theoretical foundation of Lean at the design stage can contribute to the considerable reduction of construction waste in the construction process. The authors identified that the most significant causes of waste at the design phase are related to design changes, poor decision making, lack of information exchange, and poor communication, among others. Consequently the integration of both disciplines at this stage would reduce design time, reworks and conflicts [49], at the same time that increases predictability, and stakeholder interaction [47], [48].

Also about design error management, Al Hattab and Hamzeh [50] analysed how BIM and Lean practice reorganize the structures and communication of the participants in the design phase in order to identify omissions and errors at the design stage before they can have severe impacts on subsequent phases and the overall project, and reduce their recurrence.

Other authors extend the synergy to other stages of the project life cycle as the construction phase. Specifically, in Tauriainen et al. [51] Lean is presented as a BIM Facilitator to foster collaboration through Lean tools like big room, knotworking, Last planner and set based design is highlighted to overcome barriers related to human relations, such as unclear responsibilities, inadequate instructions and lack of communication, that impede the correct implementation of BIM. Furthermore, is widely known the benefits of $\mathrm{BIM}$ in terms of the visualisation as $3 \mathrm{D}$ modelling software. However, not only will allow the construction process visualisation in the design phase but also will enable Lean principles to be used in construction projects to achieve better project performance by increasing productivity and quality and reducing cost as well as project delivery time [36].

The review of the literature shows the scarcity of works on the synergy of both paradigms taking into account the extensive literature on Lean and BIM separately. Furthermore, if we look beyond the theoretical literature reviews, we observed that this low percentage extends also to the case studies works, so there are hardly any researches in indexed journals or papers in highly relevant conferences on the subject that focus on the integration of these paradigms collectively through case studies.

Within this scant existing literature, in Clemente and Cachadinha [52] is studied the BIM and Lean synergies through a case study. But despite it was developed in the construction phase it only focuses on the management of MEP works such as plumbing and electrical facilities. Also in De Mattos Nascimento et al. [53] the BIM and Lean alignment is studied through its application on a real-world case study, but it is only focused on the facility management stage and not in the construction phase. Likewise, in Bhatla and Leite [54] is achieved the integration of BIM and Lean concepts such as the Last planner system in a case study, but again in the operation and maintenance phase. 
During the literature review just a few articles that include case studies and are focused on the construction phase have been found. In Koseoglu et al. [55] the construction project of the Istanbul Grand Airport was carried out within a BIM Lean comprehensive approach, achieving a successful management not only at the design stage but also covering the construction phase. As well in Mahalingam et al. [56] a case study of a metro rail station project in India with the implementation of BIM and Last planner system was compared with another metro rail station project were only BIM was implemented. The main results showed how Lean practices create a culture of coordination, improving coordination within a project team and enable BIM adoption maximizing its use for decision making.

About BIM assistance in decision making on short and medium term planning and control was also described in Garrido et al. [57] where two case studies of residential construction projects were carried out. Another main result identified in the research were single information source, automated clash checking, visualization of process status and online communication of product and process information. Similarly, synergies and integration have been analysed in Toledo et al. [58] where a coordinated use of Last planner system and BIM facilitates the interaction and communication of different project stakeholders around BIM management in planning meetings.

As it is shown in Fig. 1 the content analysis after the paper sampling derived in two types of information. First, a qualitative analysis was performed and as a result the following sub section presents a summary of the state-of-the-art in BIM and Lean synergies. In addition, Fig. 2 shows the benefits of the synergy of both paradigms and how they empower each other, according to the revision of contents of the paper sampling (Fig. 2). The benefits of the left column are associated with Lean techniques, while the benefits of the right column are associated with BIM benefits, according to literature analysis.

Also it was stablished a matrix (Table 1) that shows the correlation of these benefits with the problems regarding delays and cost overruns in construction works managed in a traditional way previously detected.

\begin{tabular}{|l|l|}
\hline Increases production flexibility & Fast evaluation of alternatives \\
\hline Increases process transparency & Allows visualization and process status \\
\hline Controls the entire process globallv & $\begin{array}{l}\text { Provides predictable information- quantity } \\
\text { cost, schedules, and materials }\end{array}$ \\
\hline Reduces variability & Creates and uses information early \\
\hline Proactive management & Facilitates information flow \\
\hline Avoids design mistakes & $\begin{array}{l}\text { Fosters communications/interactions } \\
\text { collaborations / coordination }\end{array}$ \\
\hline & Improves document version control \\
\hline Clash detection capabilities \\
\hline Improves scheduling capabilities \\
\hline $\begin{array}{l}\text { More clearly-defined BIM deliveries } \\
\text { between parties }\end{array}$ \\
\hline
\end{tabular}

Figure 2: BIM and Lean construction synergies according to content analysis. 
Table 1: Correlation between the synergies and the problems previously identified.

\begin{tabular}{|c|c|c|c|c|c|c|c|c|c|c|c|c|c|c|c|c|}
\hline $\begin{array}{l}\text { Problems regarding } \\
\text { delays and cost } \\
\text { overruns }\end{array}$ & 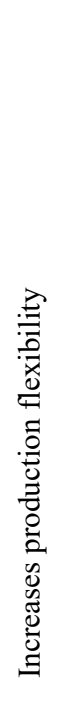 & 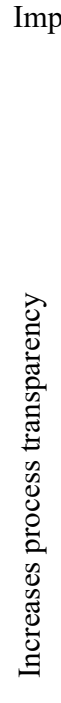 & 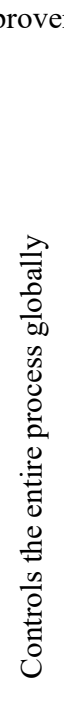 & 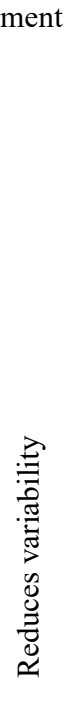 & 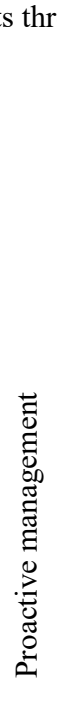 & 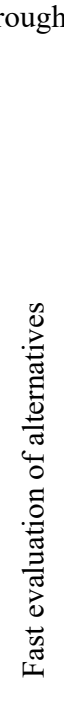 & 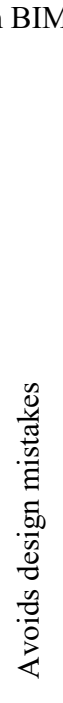 & 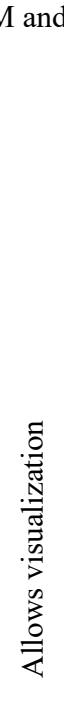 & 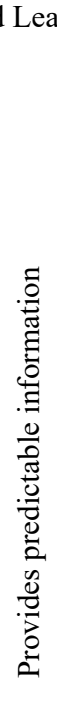 & 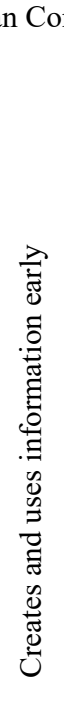 & 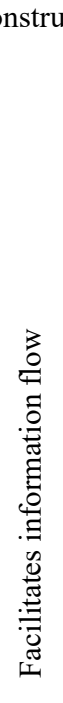 & 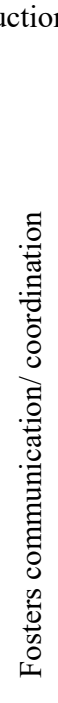 & 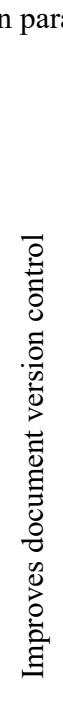 & 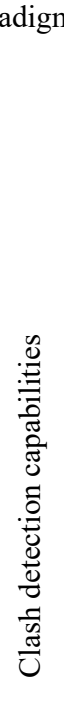 & 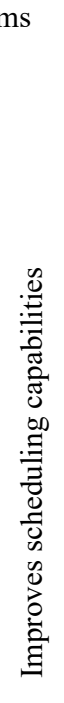 & 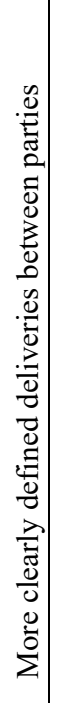 \\
\hline Poor communication & & 曰 & & & & & & घ & & घ & घ & - & & & & - \\
\hline Lack of motivation & & ! & & & & & & घ & & घ & घ & - & & & & - \\
\hline $\begin{array}{l}\text { Labor absences, } \\
\text { accidents and } \\
\text { physical demands }\end{array}$ & "घ & & & & E & & & & & & & & & & & - \\
\hline Changes in orders & - & & & ш & - & - & & & & - & - & - & - & - & & \\
\hline Design errors & & & & ш & घ & & - & घ & & - & - & & & - & & \\
\hline $\begin{array}{l}\text { Delays in resources' } \\
\text { delivery }\end{array}$ & " & & & " & " & " & & & - & & & & & & & \\
\hline $\begin{array}{l}\text { Project duration } \\
\text { overestimation }\end{array}$ & & & " & & घ & घ & & & - & " & & & & & " & \\
\hline $\begin{array}{l}\text { Lack of information } \\
\text { exchange }\end{array}$ & & & & & & & & & & . & " & . & - & & & - \\
\hline Duplicities and errors & & & & & = & & & - & & - & - & - & & & & \\
\hline Lack of transparency & & - & & & & & & & & - & - & - & & & & - \\
\hline $\begin{array}{l}\text { Breakdowns and } \\
\text { malfunctions of tools }\end{array}$ & " & & & (1) & ㅁ & & & & & & & & & & & \\
\hline $\begin{array}{l}\text { Environmental } \\
\text { effects }\end{array}$ & 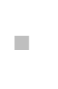 & & " & " & " & - & & & & & & & & & & \\
\hline Lack of control & & & घ & & - & & & - & 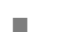 & - & & & - & - & & \\
\hline $\begin{array}{l}\text { Poor decision } \\
\text { making }\end{array}$ & & & & & & - & - & I & & & " & & & " & & \\
\hline $\begin{array}{l}\text { Unclear } \\
\text { responsibilities }\end{array}$ & & 口 & ㅁ. & & 口 & & & & & & & & & & & घ \\
\hline
\end{tabular}




\subsection{Quantitative research results}

Second, a sample's quantitative analysis was developed and provided an overview about: the lifecycle stage where the researches of the paper sampling are focus on, the main discipline of the research, the research dissemination vehicle and the profile of research according to if it is a theoretical work or a case study. The findings of the quantitative analysis are shown in Fig. 3, where is highlighted that most of the research on BIM and Lean construction synergies published indexed journals or papers in highly relevant conferences on the subject are focused on the design phase, compared to the rest of the life cycle phases. Furthermore, results showed that most of them are focused on the architecture discipline versus MEP discipline. In addition, it was detected that despite the fact that most of them use journals as the research dissemination vehicle, contributions to specific international relevant conferences on the subject also represent a high percentage. Finally, it was detected that there is a balance between the percentage of theoretical research and case studies in this field.

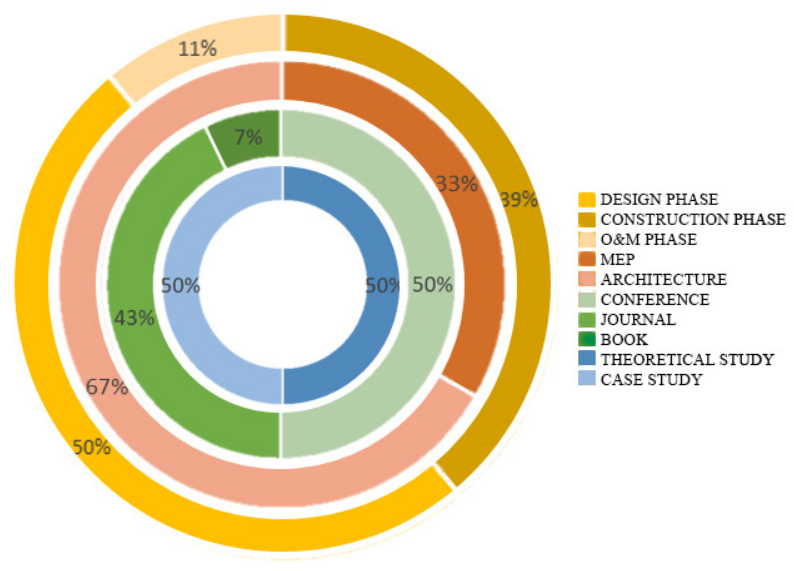

Figure 3: Quantitative research results.

\section{CONCLUSIONS}

This study reveals that research on BIM and Lean construction synergies converge in the bidirectional improvements of both paradigms, as they empower each other. It has been concluded that they enhance improvements in throughout project life cycle: early design, design and detail, construction, fit-out and handover, and facilities management and operations. In this sense, BIM contributes directly to Lean goals empowering Lean processes contributing to the considerable reduction of construction waste in the construction process such as design changes, poor decision making, lack of information exchange, and poor communication. At the same time Lean processes facilitate the adoption and use of BIM overcoming unclear responsibilities, inadequate instructions and lack of communication, that impede the correct implementation of BIM.

Also, the review of the literature shows the scarcity of works on the synergy of both paradigms taking into account the extensive literature on Lean and BIM separately. Therefore, it can be concluded that the interaction BIM and Lean Construction is an area still little explored that can open future lines of research associated to Lean tools beyond the Last Planner system, and other agile management systems. 


\section{REFERENCES}

[1] Love, P.E. et al., Determining the probability of project cost overruns. Journal of Construction Engineering and Management, 139(3), pp. 321-330, 2012.

[2] Plebankiewicz, E., Model of predicting cost overrun in construction projects. Sustainability, 10(12), pp. 4387, 2018.

[3] Andújar-Montoya, M. et al., A construction management framework for mass customisation in traditional construction. Sustainability, 7(5), pp. 5182-5210, 2015.

[4] Alshawi, M. \& Ingirige, B., Web-enabled project management: an emerging paradigm in construction. Automation in Construction, 12(4), pp. 349-364, 2003.

[5] Aziz, R.F. \& Hafez, S.M., Applying Lean thinking in construction and performance improvement. Alexandria Engineering Journal, 52(4), pp. 679-695, 2013.

[6] Love, P.E. \& Edwards, D.J., Forensic project management: The underlying causes of rework in construction projects. Civil Engineering and Environment Systems, 21(3), pp. 207-228, 2001.

[7] Love, P.E., Influence of project type and procurement method on rework costs in building construction projects. Journal of Construction Engineering and Managment, 128(1), pp. 18-29, 2002.

[8] Hwang, B.-G. et al., Measuring the impact of rework on construction cost performance. Journal of Construction Engineering and Managment, 135, pp. 187-198, 2009.

[9] Akinci, B. et al., A formalism for utilization of sensor systems and integrated project models for active construction quality control. Automation in Construction, 15(2), pp. 124-138, 2006.

[10] Josephson, P.E. \& Hammarlund, Y., The causes and costs of defects in construction: A study of seven building projects. Automation in Construction, 8, pp. 681-687, 1999.

[11] Andújar-Montoya, M.D., Integral Construction Management Model for Mass Customisation in Residential Building. An Approach Based on BPM, Building Sciences and Urbanism Department. University of Alicante Polytechnic School EPSA2015, University of Alicante: Alicante (Spain).

[12] Andújar-Montoya, M. et al., A context-driven model for the flat roofs construction process through sensing systems, internet-of-things and last planner system. Sensors, 17(7), pp. 1691, 2017.

[13] Choo, H.J. \& Tommelein, I.D., Requirements and barriers to adoption of last planner computer tools. 9th Annual Conference of the International Group for Lean Construction (IGLC-9), Singapore. p. 6-8, 2001.

[14] Abdelhamid, T.S. \& Everett, J.G., Physical demands of construction work: A source of workflow unreliability. Proceedings of the 10th Conference of International Group for Lean Construction, 2002.

[15] Calveras, A.G., José, J. \& Hauk, E., Las bajas temerarias en las subastas de obras públicas. Un análisis de la regulación española. Spanish Public Treasury/Journal of Public Economics, pp. 135-153, 2002.

[16] CEOE, Investment in Public Infrastructures in Spain. Proposal to Improve the Legal Framework and the Practice of Public Procurement in the Area of Concessions and Public-Private Collaboration. Spanish Confederation for Entrepreneur Organizations, 2013.

[17] Porwal, A. \& Hewage, K.N., Building Information Modeling (BIM) partnering framework for public construction projects. Automation in Construction, 31, pp. 204-214, 2013. 
[18] Galiano-Garrigós, A. \& Andújar-Montoya, M.D., Building Information Modelling in operations of maintenance at the University of Alicante. International Journal of Sustainable Development and Planning, 13(1), pp. 1-11, 2017.

[19] Koskela, L., Application of the new production philosophy to construction, Stanford University (Technical Report No. 72, Center for Integrated Facility Engineering, Department of Civil Engineering): Stanford, CA, 1992.

[20] Koskela, L., Lean Production in Construction, A.A. Balkema Publishers, 1997, pp. 1-9.

[21] Koskela, L., Management of production in construction: a theoretical view. In Proceedings of the 7th Annual Conference of the International Group for Lean Construction, Berkeley, California, USA, 1999.

[22] Koskela, L. \& Howell, G., The theory of project management: Explanation to novel methods. Proceedings 10th Annual Conference of the International Group for Lean Construction IGLC-10. Gramado, Brazil, 2002.

[23] Koskela, L. et al., If CPM is so bad, why have we been using it so long? 22th International Group for Lean Construction conference (IGLC 22), Oslo, 2014.

[24] Dos Santos, A. \& Powell, J., Potential of poka-yoke devices to reduce variability in construction. 7th Annual Conference of the International Group for Lean Construction (IGLC-7), University Of California, Berkeley, California, USA, 1999.

[25] Alzraiee, H., Zayed, T. \& Moselhi, O., Dynamic planning of construction activities using hybrid simulation. Automation in Construction, 49, pp. 176-192, 2015.

[26] Ballard, G. \& Howell, G., An update on last planner. 11th Annual Conference of the International Group for Lean Construction (IGLC-11), Blacksburg, VA, 2003.

[27] Ballard, H.G., The last planner system of production control, Doctoral dissertation, University of Birmingham, 2000.

[28] Tommelein, I.D. \& Ballard, G., Look-Ahead Planning: Screening and Pulling, pp. 2021, 1997.

[29] Muñoz, S., Openbim, estandarizar para afrontar los nuevos retos del mercado, BuildingSMART Spanish Chapter, 2016.

[30] Azhar, S. et al. Building Information Modeling (BIM): A new paradigm for visual interactive modeling and simulation for construction projects. Proc. First International Conference on Construction in Developing Countries, 2008.

[31] Succar, B., Building information modelling framework: A research and delivery foundation for industry stakeholders. Automation in construction, 18(3), pp. 357-375, 2009.

[32] Azhar, S., Khalfan, M. \& Maqsood, T., Building information modeling (BIM): now and beyond. Australasian Journal of Construction Economics and Building, 12(4), pp. 15, 2012.

[33] Bryde, D., Broquetas, M. \& Volm, J.M., The project benefits of building information modelling (BIM). International Journal of Project Management, 31(7), pp. 971-980, 2013.

[34] Miettinen, R. \& Paavola, S., Beyond the BIM utopia: Approaches to the development and implementation of building information modeling. Automation in Construction, 43, pp. 84-91, 2014.

[35] Khanzode, A., Fischer, M. \& Reed, D., Benefits and lessons learned of implementing building virtual design and construction (VDC) technologies for coordination of mechanical, electrical, and plumbing (MEP) systems on a large healthcare project. Journal of Information Technology in Construction, 13(22), pp. 324-342, 2008. 
[36] Azhar, S., Building information modeling (BIM): Trends, benefits, risks, and challenges for the AEC industry. Leadership and Management in Engineering, 11(3), pp. 241-252, 2011.

[37] Report, M.H.C., The Business Value of BIM in North America, 2012.

[38] Zhang, X. et al., Using Building Information Modelling to achieve Lean principles by improving efficiency of work teams. International Journal of Construction Management, 18(4), pp. 293-300, 2018.

[39] Bryde, D., Broquetas, M. \& Volm, J.M., The project benefits of building information modelling (BIM). International Journal of Project Management, 31(7), pp. 971-980, 2013.

[40] Chen, S.M., Chen, P.H. \& Chang, L.M., A framework for an automated and integrated project scheduling and management system. Automation in Construction, 35, pp. 89-110, 2013.

[41] Hardin, B. \& McCool, D., BIM and Construction Management: Proven Tools, Methods, and Workflows, John Wiley \& Sons, 2015.

[42] Chong, H.Y., Lee, C.Y. \& Wang, X., A mixed review of the adoption of Building Information Modelling (BIM) for sustainability. Journal of Cleaner Production, 142, pp. 4114-4126, 2017.

[43] Ghaffarianhoseini, A. et al., Building Information Modelling (BIM) uptake: Clear benefits, understanding its implementation, risks and challenges. Renewable and Sustainable Energy Reviews, 75, pp. 1046-1053, 2017.

[44] Daniel, E.I., Pasquire, C. \& Dickens. G., Exploring the implementation of the Last Planner $^{\circledR}$ System through IGLC community: twenty one years of experience. 23rd Annual Conference of the International Group for Lean Construction, Perth, Australia, 2015.

[45] Babalola, O., Ibem, E.O. \& Ezema, I.C., Implementation of Lean practices in the construction industry: A systematic review. Building and Environment, 2018.

[46] De Carvalho, A., Granja, A. \& Da Silva, V., A systematic literature review on integrative Lean and sustainability synergies over a building's lifecycle. Sustainability, 9(7), pp. 1156, 2017.

[47] Dave, B. et al., Implementing Lean in Construction: Lean Construction and BIM, CIRIA, 2013.

[48] Mollasalehi, S. et al. Development of an experimental waste framework based on $\mathrm{BIM} /$ Lean concept in construction design. 24th Annual Conference of the International Group for Lean Construction, Boston, MA, USA, 2016.

[49] Sacks, R. et al., Interaction of Lean and building information modeling in construction. Journal of Construction Engineering and Management, 136(9), pp. 968-980, 2010.

[50] Al Hattab, M. \& Hamzeh, F., Using social network theory and simulation to compare traditional versus BIM-Lean practice for design error management. Automation in Construction, 52, pp. 59-69, 2015.

[51] Tauriainen, M. et al., The effects of BIM and Lean construction on design management practices. Procedia Engineering, 164, pp. 567-574, 2016.

[52] Clemente, J. \& Cachadinha, N., Bim-Lean synergies in the management on mep works in public facilities of intensive use-A case study. 21st Annual Conference of the International Group for Lean Construction IGLC 21, International Group for Lean Construction: Federal University of Ceara, Brazil, pp. 751-759, 2013.

[53] De Mattos Nascimento, D.L., Quelhas, O.L.G., Meiriño, M.J., Caiado, R.G.G., Barbosa, S.D. \& Ivson, P., Facility management using digital Obeya room by 
integrating BIM-Lean approaches-an empirical study. Journal of Civil Engineering and Management, 24(8), pp. 581-591, 2018.

[54] Bhatla, A. \& Leite. F., Integration framework of BIM with the Last Planner System TM. 20th Conference of the International Group for Lean Construction, San Diego, USA, 2012.

[55] Koseoglu, O., Sakin, M. \& Arayici, Y., Exploring the BIM and Lean synergies in the Istanbul Grand Airport construction project. Engineering, Construction and Architectural Management, 25(10), pp. 1339-1354, 2018.

[56] Mahalingam, A., Yadav, A.K. \& Varaprasad, J., Investigating the role of Lean practices in enabling BIM adoption: evidence from two Indian cases. Journal of Construction Engineering and Management, 141(7), 2015.

[57] Garrido, M.C. et al., Using BIM for last planner system: case studies in Brazil. 2015 International Workshop on Computing in Civil Engineering, Austin, Texas, 2015.

[58] Toledo, M., Olivares, K. \& González, V., Exploration of a Lean-BIM planning framework: A last planner system and BIM-based case study. 24th Annual Conference of the International Group for Lean Construction, IGLC 2016, National Pingtung University of Science and Technology: Boston, Massachusetts, USA, 2016. 